\title{
User involvement as sharing knowledge - an extended perspective in patient education
}

\author{
This article was published in the following Dove Press journal: \\ Journal of Multidisciplinary Healthcare \\ I December 2014 \\ Number of times this article has been viewed
}

\section{Anita Strøm ${ }^{\prime}$ May Solveig Fagermoen ${ }^{2}$ \\ 'Department of Masters and Continuing Education, Lovisenberg Diaconal University College, Oslo, Norway; ${ }^{2}$ nnstitute of Health and Society, University of Oslo, Oslo, Norway}

Background: Patient education is undergoing a paradigm shift in which the perspectives of patients are increasingly being incorporated into learning programs. Access to the users' experience is now considered a prerequisite for the development of quality health services, but how this user experience is incorporated is somewhat unclear. The inclusion of experiential knowledge and user involvement can challenge professional authority, roles, and working methods because knowledge sharing is different from persuasion, professional explanation, and consent. Dialogue and collaboration between professionals and users are essential to effective user involvement; however, little is understood about the characteristics of their collaboration.

Objective: To describe characteristics of the collaboration between users and health professionals in developing, implementing, and evaluating patient education courses in hospitals.

Design, setting, and methods: A field study was conducted in three different hospitals. Data collection comprised open observations in meetings of 17 different collaboration groups with a total of 100 participants, and 24 interviews with users and professionals. The data analyses included both thematic and the Systematic Data Integration approach.

Results: Two contrasting types of collaboration emerged from the analyses; knowledge sharing and information exchange. The first was characterized by mutual knowledge sharing, involvement, and reciprocal decision making. Characteristics of the second were the absence of dialogue, meagre exploration of the users' knowledge, and decisions usually made by the professionals.

Conclusion: Collaboration between users and health personnel takes place in an asymmetric relationship. Mutual knowledge sharing was found to be more than the exchange of information and consultation and also to be a prerequisite for shared decision making. In developing patient education when users are involved the health professionals have the power and responsibility to ensure that knowledge sharing with users takes place.

Keywords: user involvement, patient education, professional-patient relations, knowledge sharing

\section{Introduction}

Patients with different chronic conditions are an economically significant patient group everywhere in the world. Therefore, it is important that patient education is designed together with patients in order to decrease harmful side effects that are related to the knowledge deficiencies of the patients. Patient education is undergoing a paradigm shift in which the perspectives of patients are increasingly being incorporated into learning programs. Access to the users' experience is now considered a prerequisite for
Correspondence: Anita Strøm Lovisenberg Diaconal University College, Lovisenberggt I5B, 0456 Oslo, Norway

Tel +479502 |49|

Fax +47 22374934

Email anita.strom@Idh.no (c) (i) (5) 2014 Strom and Fagermoen. This work is published by Dove Medical Press Limited, and licensed under Creative Commons Attribution - Non Commercial (unported, v3.0) BY LC License. The full terms of the License are available at http://creativecommons.org/licenses/by-nc/3.0/. Non-commercial uses of the work are permitted without any further permission Fove Medical Press Limited, provided the work is properly attributed. Permissions beyond the scope of the License are administered by Dove Medical Press Limited. Information on how to request permission may be found at: http://www.dovepress.com/permissions.php 
the development of quality health services, but how this user experience is incorporated is somewhat unclear. ${ }^{1-4}$ It is widely believed that user involvement requires participation in shared decision making, with dialogue being a prerequisite..$^{2,3,5,6}$ In an interview study, Rise et $\mathrm{al}^{7}$ found that both users and health professionals describe user involvement as a dialogue where the goal is shared decisions. However, significant barriers to user involvement and shared decision making have been identified, including inequality, lack of power, and few genuine opportunities for contributing to decisions within the health service. ${ }^{8-12}$ Furthermore, the inclusion of experiential knowledge and user involvement can challenge professional authority, roles, and working methods, ${ }^{13}$ which have not traditionally involved users in decision making. Although dialogue and collaboration between professionals and users are essential to effective user involvement, little is understood about the characteristics of their collaboration.

One model of user involvement in decision making is practiced at the Learning and Mastery Centers (LMCs) in Norway. Based at hospitals, LMCs are competence centers that play a key role in the education and training of patients with different chronic conditions. The philosophy of the LMCs is grounded in equality between users and health professionals and the integration of user experience with professional knowledge. LMC patient education courses address the coping challenges for both patients and their relatives to enable them to live with the changes in their daily life. In LMC courses, the experiences of the users are regarded as equally important as the contributions of the professionals. Thus, the user representatives are given a completely new role as equal contributors in the health service. A collaboration group is set up for each learning program being developed at the LMCs. The group normally consists of two user representatives from the relevant user organization, relevant professionals (examples: doctor, nurse, physiotherapist), and the director of the center. The professionals are at work and return to their job site after the group meeting. The planning, implementation, and evaluation of each learning program is this group's responsibility.

Although professionals and users routinely collaborate to meet the LMCs' patient education and user involvement goals, the characteristics of these collaborations have not been previously studied. Thus, the purpose of this study was to describe the collaboration between professionals and users in the process of developing LMC learning programs for the chronically ill. ${ }^{14}$ The study included patients and next of kin (both considered "users"), as well as various health professionals as they collaborated on the planning, implementation, and evaluation of patient education courses. The research question was: "What characterizes the users' involvement in the collaboration process at LMCs?" This article describes two contrasting types of collaboration that emerged from the analyses: knowledge sharing and information exchange.

\section{Methods}

\section{Setting, participants, and data collection}

A field study was conducted in LMCs at three different locations in Norway (Oslo University Hospital, Oslo; Notodden Hospital, Notodden; and Nordland Hospital, Bodø). These LMCs offered patient education based on the same ideology and had similar patient groups attending their courses. We observed the collaborations of 17 different groups of users and health professionals with altogether 100 participants. The group size varied from four to 12 participants. When the groups started to plan the course, some were meeting for the first time, while others had prior experience working together to develop courses. The group meetings were led by one LMC professional. The field notes were based on open observations in 46 collaboration meetings, with most groups being observed several times. Further, ten users and 14 health professionals were individually interviewed in accordance with a thematic interview guide focusing on their experience of participating and offering personal or professional experience and competence. The interviews were conducted soon after the field observations by the same researcher who also recorded and transcribed these verbatim. Reflective notes were taken. Average interview time was 40 minutes.

\section{Analysis}

We used several analytical techniques, alternating between open reading and theme-focused reading. ${ }^{15-18}$ The field notes and transcriptions were analyzed both separately and in light of each other. Main themes were identified in the field notes and supported by a considerable number of sub-themes from the interview transcriptions.

To further explore aspects of collaboration through a more integrated analysis, we developed a new method for Systematic Data Integration (Figure 1). ${ }^{19}$ Researchers are encouraged to view field notes and interview texts as a complete body of material for analysis. ${ }^{16,20}$ This new method involved interweaving observation data and interview data from group interactions and was inspired from a similar method used on analysis of events. ${ }^{21}$ The meetings in all of the collaboration groups focused on the planning, implementation, and evaluation of the course. This series of meetings is named as sequences of interaction. 


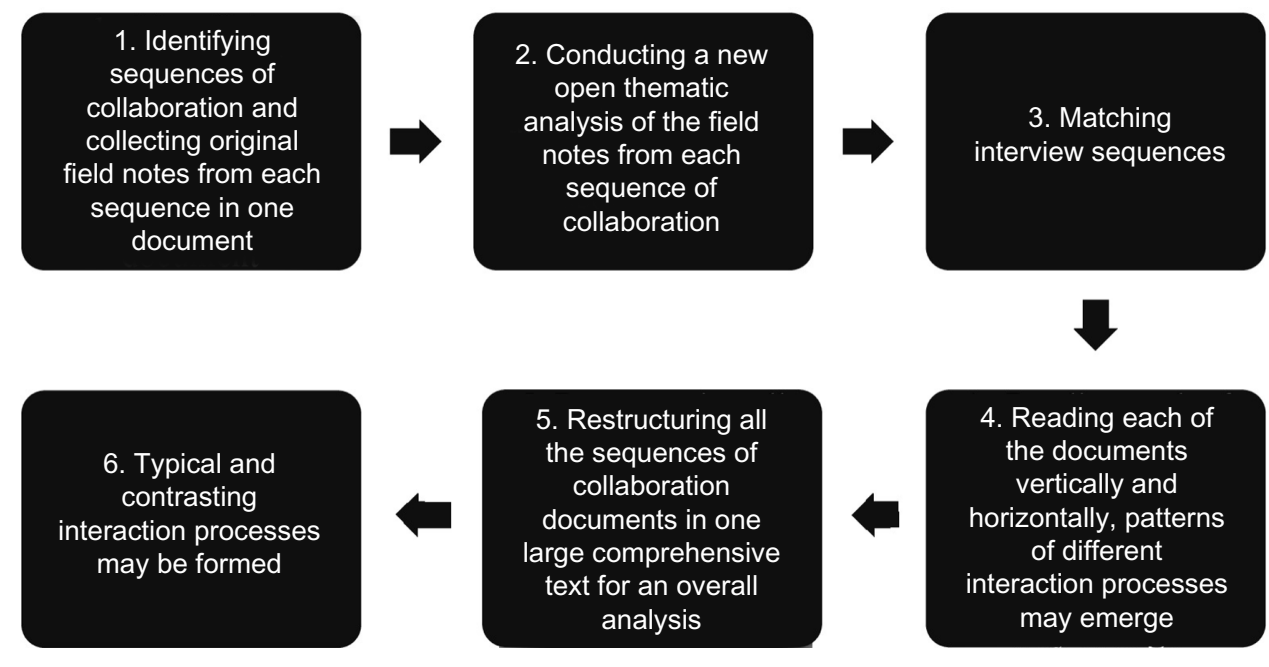

Figure I Illustration of the Systematic Data Integration.

For each sequence of collaboration, raw data from field notes were first placed in the left side column in a document and subjected to thematic analysis. Then the identified themes were placed in the middle column, and matching interview sequences in the right side column (Table 1).

The result of this first interweaving process was a reconstructed and integrated text from each sequence of collaboration. Each reconstructed text was then read vertically and horizontally to more fully explore these sequences of collaboration. In the second interweaving process, all the reconstructed sequences of collaboration were put together in a large comprehensive text. This last integrated analysis was guided by the question: "What characterizes these collaboration processes?" In Interweaving the texts in this manner was essential for creating an overall perspective and acquiring integrated material for further analyses.

\section{Ethical considerations}

The Data Protection Official for Research in Norway approved the study (Ref no 11247). Written informed consent was obtained from all participants and all aspects of confidentiality and anonymity were ensured.

\section{Results}

The main finding from the Systematic Data Integration revealed the collaboration process to be a complex phenomenon that varied from dynamic to passive, depending on different combinations of participant types. The first integrated analysis, the thematic analysis of interwoven field notes and interview texts, revealed several types of users and professionals (Tables 2 and 3 ). Three types of users were identified based on clear differences in how they shared their experiences and participated in the group. Three types of professionals were identified based on differences in how they acted and what they shared in the group.

Table I Extract from an extensive text illustrating the first interweaving process

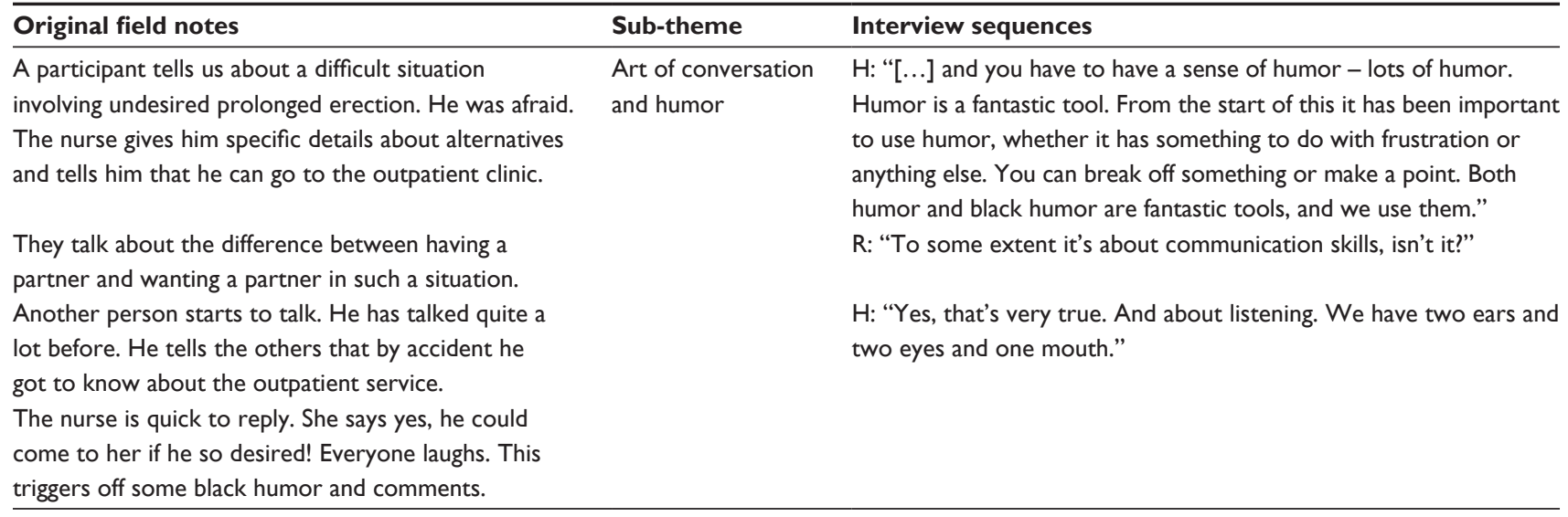

Note: Copyright @ 2010. Adapted from Strøm A. Samarbeid i Lærings- og mestringssenteret: brukermedvirkning og makt [Collaboration in the Learning and Mastery Centers - User Participation and Power] [Doctoral dissertation]. Oslo, Unipub; 2010.14 
Table 2 Types of users

\begin{tabular}{lll}
\hline $\begin{array}{l}\text { Types } \\
\text { of users }\end{array}$ & $\begin{array}{l}\text { Characteristics of how } \\
\text { they share their own } \\
\text { experience }\end{array}$ & $\begin{array}{l}\text { Relation to other group } \\
\text { members and their } \\
\text { contributions }\end{array}$ \\
\hline Novice & $\begin{array}{l}\text { Entire story unpolished } \\
\text { Appealing narratives } \\
\text { Everyday language }\end{array}$ & $\begin{array}{l}\text { No concern with the } \\
\text { application of their own } \\
\text { knowledge }\end{array}$ \\
Advanced & $\begin{array}{l}\text { Share selective parts of } \\
\text { their own experiences }\end{array}$ & $\begin{array}{l}\text { A clear understanding of } \\
\text { others' perceptions as } \\
\text { different from their own } \\
\text { Willing to confirm or correct } \\
\text { the professionals' input }\end{array}$ \\
& & Equal partner \\
& & Promote important issues \\
& Less emphasis on their & Negotiate \\
& Focus on experiences as & \\
& a group phenomenon & \\
\hline
\end{tabular}

In the second integrated analyses, we were looking for whether and how the core values of the LMC, equality in both partnership and forms of knowledge (eg, experiential versus professional), were realized in the collaboration process. In the following sections, two contrasting collaboration processes, referred to as "information exchange" and "knowledge sharing", are presented (Table 4).

There were fewer collaboration processes of the type information exchange than of knowledge sharing. The findings are exemplified with representative extracts from different group meetings.

\section{Information exchange}

The most prominent feature of this passive type of collaboration process was the absence of dialogue (ie, egalitarian communication about a common cause). Further, there were few signs of recognition of users' knowledge, and a passive form of interaction characterized the group discussions.

Table 3 Types of health professionals

\begin{tabular}{lll}
\hline $\begin{array}{l}\text { Types of } \\
\text { health } \\
\text { professionals }\end{array}$ & $\begin{array}{l}\text { Relation to core values } \\
\text { of the LMC }\end{array}$ & $\begin{array}{l}\text { Orientation } \\
\text { toward user } \\
\text { experience }\end{array}$ \\
\hline Co-worker & $\begin{array}{l}\text { Present, curious, and engaged } \\
\text { to learn }\end{array}$ & $\begin{array}{l}\text { Focuses on equality, } \\
\text { interest in, and } \\
\text { acknowledgement of } \\
\text { insider knowledge }\end{array}$ \\
Visitor & $\begin{array}{l}\text { Arrives, delivers a professional } \\
\text { contribution, and leaves }\end{array}$ & $\begin{array}{l}\text { Low interest } \\
\text { and no concern } \\
\text { demonstrated }\end{array}$ \\
& $\begin{array}{l}\text { Promotes friendliness, fairness, } \\
\text { Group leader }\end{array}$ & $\begin{array}{l}\text { Facilitates to provide } \\
\text { space for users' views }\end{array}$ \\
& $\begin{array}{l}\text { Balances tensions } \\
\text { Collects support for common } \\
\end{array}$ & \\
\hline
\end{tabular}

Abbreviation: LMC, Learning and Mastery Center.
Table 4 Main features of the two types of collaboration processes

\begin{tabular}{ll}
\hline $\begin{array}{l}\text { Main features of information } \\
\text { exchange }\end{array}$ & $\begin{array}{l}\text { Main features of knowledge } \\
\text { sharing }\end{array}$ \\
\hline $\begin{array}{l}\text { Group primarily composed of novice } \\
\text { users and the visitor type of health }\end{array}$ & $\begin{array}{l}\text { Groups composed of a mixture } \\
\text { of several types of users and } \\
\text { professional }\end{array}$ \\
$\begin{array}{ll}\text { Few signs of professionals' } \\
\text { recognition of users' knowledge }\end{array}$ & $\begin{array}{l}\text { Mutual acknowledgment of } \\
\text { each other as persons and each } \\
\text { other's knowledge contributions }\end{array}$ \\
A passive form of interaction in & $\begin{array}{l}\text { Exploratory interaction in } \\
\text { discussions }\end{array}$ \\
discussions & Dialogue \\
Finsence of dialogue & Joint decisions \\
leader & \\
\hline
\end{tabular}

This may be due to the composition of the groups, which were primarily composed of novice users and the visitor type of health professional. The following extract from the field notes is a representative example of a first time group meeting:

Six people in white coats sit beside each other parallel to the row of windows. The users, the leader, and me as an observer sit on the other side. Bleepers disturb us constantly, and the health professionals frequently have to leave the room. The leader welcomes the group, and asks everyone to introduce themselves and say something about their views on the learning program to be planned. The users spend considerable time telling their comprehensive narratives. The health professionals ask no follow-up questions. The leader requests more details of some aspects. The health professionals are more concise than the users, both when they introduce themselves and in their comments on the learning program. As far as I can see the health professionals seldom initiate any discussions. I wonder why there is so little commitment to what is to be created and decided on. Suddenly something happens: one of the professionals has a strong opinion about what "must be included" and says, "If there's any point in it at all, we can't leave this out [...]". After some back and forth between this physiotherapist and the leader, the leader takes over: "We have to make our minds up. Am I to understand that we include these topics?" No comments. The leader's eagerness to make a decision and the health professionals' insistence on important elements that are to be included seems to form the outcome.

The health professionals' reluctance in relating to the users' experiences as relevant knowledge, can be referred to as a "waiting attitude". This attitude may portray a lack of commitment to collaborate. After a round of such presentations the users seemed withdrawn. The health professionals resembled visitors rather than co-workers (Table 3). In the 
group meetings, the health professionals often came late and/or left early. They seemed to have no spare time to participate and appeared uninterested in the users' comprehensive narratives. Keeping their distance is also illustrated by the seating arrangement described above. This passive collaboration process can best be described as an exchange of information: each participant gave their opinions, with little connection to others' opinions. The leader tried to generate information and struggled to create conditions for collaboration. Both user experience and professional knowledge were displayed in the group but as parallel dimensions that appeared to have little connection. Most often, professional knowledge appeared to have prime importance, and consequently, the course program reflected a traditional focus on illness and treatment.

The group leader engaged in facilitating the process, but several attempts to encourage the group members to exchange opinions were unsuccessful. When the time came to make decisions, the leader often became proactive with regard to what was to be included and who was to contribute to the course. When one of the leaders was asked if she thought that everyone had had a say in the decision, her position regarding reaching a result became clear:

No. One goal could have been to get everybody to say some-

thing, but I think the goal is really more to reach a result. So

what actually happens is that those who have something to

say jump in. And then we have to make a decision.

In such a process, the health professionals set the terms for the interaction. They seemed to lack the basic abilities and/or attitudes necessary for collaboration and behaved as "the ones who know". Openness and curiosity toward the users' experience were uncommon. Some of these planning meetings gave an impression of a passive situation where "little happened". Even though both parties had their say, there was no logic that this created an intersection between the experiences of chronic illness and professional knowledge. Most often, the statements of the health professionals and the users remained separate and disconnected.

\section{Knowledge sharing}

The second type of collaboration had characteristics quite unlike the one described above. It was dynamic, occurred in both established and new groups, and was characterized by the participants' engagement. A mixture of several types of users and health professionals as coworkers constituted these groups. The main impression of a typical dynamic collaboration was that the dialogue reflected the participants' acknowledgment of each other as persons and each other's knowledge contributions. Commitment and exploratory interaction seemed intertwined and particularly dependent on the health professionals being engaged in the users and their experiences. The health professionals' attitude was typically both proactive with respect to exploring users' knowledge and somewhat reserved regarding themselves and their own knowledge. Not surprisingly, all types of users were interested in the professionals' knowledge. The following field note from an introductory meeting exemplifies the exploration of each other as persons:

The leader asks the participants to introduce themselves and to say whether they know anyone else in the group from before. The health professionals are brief, for example saying, "I am physiotherapist attached to the stroke unit at the hospital". The users take a little more time to tell about the date of their stroke, their reactions, the outcome, the practical consequences, and why they agreed to be part of this working group. "It has cost so much to figure things out and to find solutions", one of the women says. "I wouldn't wish it on anyone else. Maybe I can make a contribution". None of the health professionals say anything about whether they know the user representatives. The male user refers to the ergonomist and says, "The last time I saw her she was with me in the shower". Everyone laughs, and she replies, "Circumstances were quite different then."

The following field note further exemplifies the exploration of significant knowledge that the parties bring into the planning of the course:

The group leader asks the users if they have any special wishes for the meeting. One next of kin comments that "sexuality" is important. The physiotherapist says that the brochure she has compiled on the topic disappeared when it was circulated for comments. The leader then laughs and says, "booklets on strokes and sex always disappear". The doctor asks the group leader: "Have you covered this topic before?" and "What were people most interested in then?"

A next of kin shares the view that there should be an interaction between users and health professionals. He thinks it would be a good idea if somebody summarized some of the literature and, as he puts it, "added something of his own experience". The leader asks if this means that he will do it, and he agrees to do so.

The doctor says, "Little knowledge exists of this area, mostly human experience.” A younger user thinks that it must 
be presented in a way that gives people pegs to hang things on:

"We must dare to talk about the challenges." Then the next of kin says it would be a good idea to include some facts - for example hygiene. The younger user says, "Include depression [...]"'The doctor wants to say something about bodily matters. The leader makes the program more specific: the next of kin is given 15 minutes to review the important points and his own experience. "As far as I can [...]," he replies.

These descriptions of reciprocal engagement and exploration of knowledge exemplify the conceptualization of knowledge sharing. In this dynamic collaboration, knowledge sharing led to learning processes - especially for the professionals. The following example illustrates how an abruption of the discussion led to reflective views of health professionals' own contribution: the leader asked, "What have we learned so far? What type of reciprocal knowledge do we now have at our disposal for the job we are to do?" Two health professionals responded: "I've only partly understood what the users are most interested in hearing about;" "I must do this [my lecture] differently from what I had planned."

When planning courses, decisions had to be made. During this process some users were listening to the dialogue, while some dared to disagree and raised questions, sometimes critical ones, about the suggested choices and solutions. The planning proceeded toward a conclusion by a clarification of the content, the methods, and who was to contribute. The health professionals generally took the lead in the concluding phase, but some users were definitively involved:

\footnotetext{
After some discussion, the leader concluded that the "Group" ought to distribute an information brochure. Suddenly one of the users starts to speak. He has strong views on the brochure. $\mathrm{He}$ is negative towards this Norwegian Cancer Society's brochure. He suggests sending out a brochure from a medical company, and says that the language is much milder, which is important for helping people not to get depressed when they have been diagnosed. He had not dared to show the first brochure to his wife. The conclusion is that they decide not to distribute brochures at all.
}

Language and understanding were central to bringing about the dialogue. An example from a course illustrates how a physician reshaped professional expertise into knowledge for a lay audience in order to increase common comprehension:

He starts with the feedback system. "You have to understand this to be able to understand what happens to you", he says.
"You must know enough - perhaps more than your doctor to be able to cope. The textbook's level of reference doesn't seem to be completely correct in practice. You must be able to say: I want to have a blood value of 1 to feel reasonably well. It's no use being within the reference area for blood values if you don't feel comfortable and OK there," he tells them. Suddenly there is a flood of testimonies about normal blood tests and feeling wretched.

In addition to illustrating the importance of re-shaping language, this is an example of a health professional regarding user experience as trustworthy knowledge and perhaps questioning the meaning of scientific knowledge. This dynamic collaboration process was also characterized by a commitment by all to each other and to what was to be planned, an exploration of each other's viewpoints and not least the reciprocity in the decisions made. Both the content and the methods of the course resulted from contributions by users, health professionals, and the group leaders.

In summary, two contrasting collaboration processes were identified in this analysis. Distribution of knowledge was central to both processes: the first one was characterized by indifferent display of knowledge, while in the second one, there was mutual sharing of both parties' knowledge. Hence, a key finding of our study was that knowledge sharing is a critical element of effective collaboration between professionals and users, with users' involvement in knowledge sharing seemingly influenced by how health professionals relate to the users' experiences and knowledge.

\section{Discussion}

This study yielded several findings related to collaborative learning processes characterized by knowledge sharing. We found that the health professionals acquired new perspectives regarding how illness, treatment, learning, and coping affect the users' everyday life, while the users were able to continue reflecting on their experience and thus acquired new knowledge of their own. How the groups are led and how the health professionals participate is vital for both the reciprocal exchange of knowledge and consensus decisions about the course program. Similar patterns between professional practice, patient participation, and meaningful learning processes have also been described in two studies of hospitalized persons with mental illness. ${ }^{22,23}$ The aim of these studies was to describe the subjective experiences of learning processes in a therapeutic setting, and they found that atmosphere, attitudes, interpersonal relationships, equality, and recognition were factors that promoted individual learning processes. ${ }^{22,23}$ 
A knowledge-sharing type of collaboration process created space that enabled everyone to learn and promoted new joint understandings and new alternatives for action. The health professionals' participation in this type of collaboration is closely connected to what is called "the teacher role" in liberatory pedagogy. ${ }^{24}$ Research into user involvement in the health service emphasizes the sharing of knowledge as the most realistic power dimension in the collaboration between users and health professionals. ${ }^{10,25}$ It is claimed that when users share their experience, they raise problems rather than solving them, and that this represents the users' potential for power. In a review of the literature, Aujoulat et $\mathrm{al}^{26}$ explored how the concept of empowerment (which implicitly includes user involvement) was applied in patient education for the chronically ill. One finding was that processes of involvement and empowerment required selfinvolvement from both users and health professionals. Our results reflected the same finding. In a study of user involvement, Swift and Dieppe ${ }^{27}$ concluded that recognition of the patients' expertise can transform expert patients' narratives into powerful educational resources that can support other patients in similar situations.

A collaboration process of a completely different nature was also found in our study. Users told their experiences in full measure but had little impact on the planning meetings due to health professionals who were neither committed nor allowed themselves to be influenced by the users' stories. If the health professionals had been more engaged, the novice users may have participated more actively. Some health professionals were determined to inform the group of their own viewpoints by emphasizing their professional position. Such collaboration groups had access to different viewpoints, but little knowledge was shared in spite of the leaders' efforts. Freire $^{24}$ called this type of exchange of opinions without subsequent action "verbalism". This exchange of information is quite different from knowledge sharing which has a reciprocal aspect. Tritter ${ }^{28}$ claims that user involvement in the health service primarily takes place in an indirect way by the users serving as information suppliers for professional decision makers. A systematic review argued the need for clarification of what collaboration and user involvement entails in the development of both health services and professional health education. ${ }^{25}$ This review and some case studies ${ }^{12}$ question whether user involvement is to be simply an exchange of information and consultation or an equal partnership with health professionals.

Our study can perhaps provide additional clarification in this area. In light of our findings, genuine shared decision making seems to require a mutual recognition of both parties as having relevant knowledge to contribute toward a good decision. We have previously debated the crucial importance of experience as insider knowledge in patient education for the chronically ill. ${ }^{29}$ Insider knowledge is regarded as particularly reliable and is characterized by participation and first-hand experience. First-hand experience involves senses and feelings, thus providing concrete, visible, colorful, and subjectively convincing data. ${ }^{30}$ As a result, this involvement of the senses and emotions and the lively nature of the data have a strong impact on perceptions and reflections. Insider knowledge can thus contribute to both an appropriate and relevant knowledge basis in patient education. ${ }^{29}$

Achieving equivalence in asymmetric relationships and real knowledge sharing is not a straightforward procedure. ${ }^{31}$ Knowledge sharing is different from persuasion, professional explanation, and consent. We found that the process appears to entail an attitude of recognizing the other party and their knowledge as meaningful to the goal of the process, as well as a mutual sharing of knowledge where the professionals toned down some of their knowledge dominance. Hence, knowledge sharing concerns certain values that are reflected in action. Health professionals have and must take responsibility for instigating knowledge exchange, promoting mutual reflection, and initiating decisions both during and when ending the process. The fact that knowledge sharing is dominant in our study, and similarly that shared decision making is an "assisted consequence" of knowledge sharing, may be due to the ideology of the LMC.

Decision making only based on professionals' proposals is different from shared decision making based on a joint perception that both parties possess knowledge relevant to the decision-making process. We view both parties' knowledge and perspectives as crucial for making good decisions in patient education - including in one-on-one situations. Thus, it is necessary to create settings that encourage the mutual exchange of different forms of knowledge.

\section{Study strengths and limitations}

The findings of this study should be considered in light of its strengths and limitations. The collaboration groups differed in size, in combination of participants, and chronic condition. This might represent a limitation of the study. A single researcher conducted all observations and interviews. However, the researcher has considerable experience conducting such observations and interviews, ${ }^{32,33}$ and the data analysis processes were validated through detailed discussions with supervisors and other fieldwork researchers. In addition, the researcher's 
position as an outside observer may have facilitated the recognition and appreciation of themes that may be more blurred from an insider's position. Given that the results of this study are supported by research in other areas, the findings are likely transferable beyond the current context.

\section{Conclusion}

We explored collaboration processes in LMCs based on specific values of equality and the integration of different knowledge forms. We found knowledge sharing to be more than the exchange of information and consultation and also to be a prerequisite for shared decision making. The prerequisites for genuine sharing processes include several elements: mutual recognition of the other's knowledge and curiosity about participation in learning processes. Also, for the professionals it is important to be somewhat reticent with information they think is important for users. This form of user involvement in patient education requires health professionals who have specific values that are reflected in their interaction with the users. Health professionals have the power to ensure that knowledge sharing with users can take place and thus contribute to an extended perspective in patient education.

\section{Acknowledgments}

We thank Associate professor Ragnhild Hellesø at Institute of Health and Sciences, University of Oslo, for useful comments on an early draft of the manuscript. The Norwegian ExtraFoundation for Health and Rehabilitation has financially supported this project.

\section{Disclosure}

The authors declare no conflicts of interest in this work.

\section{References}

1. Fudge N, Wolfe CD, McKevitt C. Assessing the promise of user involvement in health service development: ethnographic study. BMJ. 2008; 336(7639):313-317.

2. Thompson AG. The meaning of patient involvement and participation in health care consultations: a taxonomy. Soc Sci Med. 2007;64(6): 1297-1310.

3. Tritter JQ. Revolution or evolution: the challenges of conceptualizing patient and public involvement in a consumerist world. Health Expect. 2009;12(3):275-287.

4. Tritter JQ, McCallum A. The snakes and ladders of user involvement: Moving beyond Arnstein. Health Policy. 2006;76(2):156-168.

5. Gruman J, Rovner MH, French ME, et al. From patient education to patient engagement: implications for the field of patient education. Patient Educ Couns. 2010;78(3):350-356.

6. Boyd H, McKernon S, Mullin B, Old A. Improving healthcare through the use of co-design. N Z Med J. 2012;125(1357):76-87.

7. Rise MB, Solbjor M, Lara MC, Westerlund H, Grimstad H, Steinsbekk A. Same description, different values. How service users and providers define patient and public involvement in health care. Health Expect. 2013;16(3):266-276.
8. Hanley B, Bradburn J, Evans C, et al. Involving the Public in NHS, Public Health and Social Care Research: Briefing Notes for Researchers (second edition). Eastleigh, Hampshire: INVOLVE; 2004.

9. Crawford MJ, Aldridge T, Bhui K, et al. User involvement in the planning and delivery of mental health services: a cross-sectional survey of service users and providers. Acta Psychiatr Scand. 2003;107(6): 410-414.

10. Crawford MJ, Rutter D, Manley C, et al. Systematic review of involving patients in the planning and development of health care. $B M J$. 2002;325(7375):1263.

11. Nilsen ES, Myrhaug HT, Johansen M, Oliver S, Oxman AD. Methods of consumer involvement in developing healthcare policy and research, clinical practice guidelines and patient information material. Cochrane Database Syst Rev. 2006(3):CD004563.

12. Rutter D, Manley C, Weaver T, Crawford MJ, Fulop N. Patients or partners? Case studies of user involvement in the planning and delivery of adult mental health services in London. Soc Sci Med. 2004;58(10): 1973-1984.

13. Anderson RM, Funnell MM. Patient empowerment: reflections on the challenge of fostering the adoption of a new paradigm. Patient Educ Couns. 2005;57(2):153-157.

14. Strøm A. Samarbeid i Laerings-og mestringssenteret: brukermedvirkning og makt [Collaboration in the Learning and Mastery Centers User Participation and Power] [Doctoral dissertation]. Oslo, Unipub; 2010. Norwegian.

15. Coffey A, Atkinson P. Making Sense of Qualitative Data: Complementary Research Strategies. Thousand Oaks, California: Sage; 1996.

16. Fangen K. Deltagende observasjon [Participant Observation]. Bergen: Fagbokforl; 2004. Norwegian.

17. Kvale S, Brinkmann S. Interviews: Learning the Craft of Qualitative Research Interviewing. Los Angeles, California: Sage; 2009.

18. Schatzman L, Strauss AL. Field Research: Strategies for a Natural Sociology. Englewood Cliffs, NJ: Prentice-Hall; 1973.

19. Strøm A, Fagermoen MS. Systematic data integration - a method for combined analyses of field notes and interview texts. International Journal of Qualitative Methods. 2012;11(5):534-546.

20. Polit D, Beck, BT. Nursing Research: Generating and Assessing Evidence for Nursing Practice (8th ed.) Philadelphian, PA: Lippincott Williams \& Wilkins; 2008.

21. Vatne S, Fagermoen MS. Event-oriented data integration: a qualitative strategy in studying professional practice. Res Theory Nurs Pract. 2008; 22(1):38-55.

22. Borge L, Hummelvoll JK. Patients' experience of learning and gaining personal knowledge during a stay at a mental hospital. J Psychiatr Ment Health Nurs. 2008;15(5):365-373.

23. Borge L, Rossberg JI, Sverdrup S. Cognitive milieu therapy and physical activity: experiences of mastery and learning among patients with dual diagnosis. J Psychiatr Ment Health Nurs. 2013;20(10):932-942.

24. Freire P. Pedagogy of the Oppressed. New York: Herder and Herder; 1972.

25. Langton H, Barnes M, Haslehurst S, Rimmer J, Turton P. Collaboration, user involvement and education: a systematic review of the literature and report of an educational initiative. Eur J Oncol Nurs. 2003;7(4): 242-252.

26. Aujoulat I, d'Hoore W, Deccache A. Patient empowerment in theory and practice: polysemy or cacophony? Patient Educ Couns. 2007;66(1): 13-20.

27. Swift TL, Dieppe PA. Using expert patients' narratives as an educational resource. Patient Educ Couns. 2005;57(1):115-121.

28. Tritter JQ. Public and patient participation in health care and health policy in the United Kingdom. Health Expect. 2011;14(2): 220-223.

29. Strom A, Kvernbekk T, Fagermoen MS. Parity: (im) possible? Interplay of knowledge forms in patient education. Nurs Inq. 2011;18(2): 94-101.

30. Fay B. Contemporary Philosophy of Social Science: A Multicultural Approach. Oxford: Blackwell; 1996. 
31. Forland G, Ringsberg KC. Implementation of a standardised health education in a local context. A case study. Scand J Caring Sci. 2013; 27(3):724-732.

32. Strøm A, Fagermoen MS. Lærings- og mestringssentre ved sykehus. Ny arena for samarbeid om pasientopplæring ved kronisk sykdom [Learning and Mastery Centres at hospitals. A new arena for collaboration on patient education]. Norsk Tidsskrift for Sykepleieforskning. 2004;6(1): 36-44. Norwegian.
33. Strøm A. Opplevelse av mening i livet når man lever med kroniske, ikke-maligne smerter: en studie av begrepet mening i livet innenfor rammen av en hybrid modell for begrepsutvikling (Schwartz-Barcott og Kim, 1986) [The experience of having a purpose for life while living with chronic, non-malignant pain. A study of the concept purposeful life within the frame of a Hybrid Model for Concept Development]. [master's thesis]. Oslo: University of Oslo; 1995.

\section{Publish your work in this journal}

The Journal of Multidisciplinary Healthcare is an international, peerreviewed open-access journal that aims to represent and publish research in healthcare areas delivered by practitioners of different disciplines. This includes studies and reviews conducted by multidisciplinary teams as well as research which evaluates the results or conduct of such teams or healthcare processes in general. The journal covers a wide range of areas and welcomes submissions from practitioners at all levels, from all over the world. The manuscript management system is completely online and includes a very quick and fair peer-review system. Visit http://www.dovepress.com/testimonials.php to read real quotes from published authors.

Submit your manuscript here: http://www.dovepress.com/journal-of-multidisciplinary-healthcare-journal 